Vol. 2 No. 2 (2021), Halaman 167-170

ISSN 2774-6968
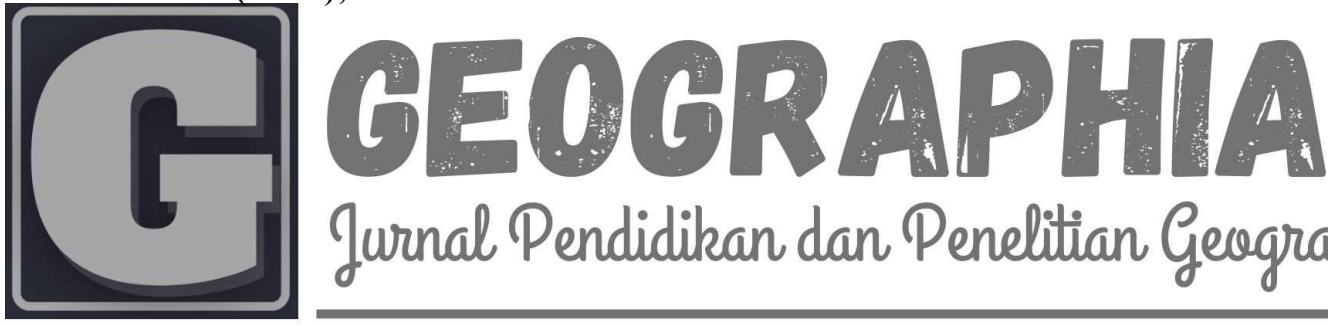

\title{
PENERAPAN PENGELOLAAN SAMPAH BERBASIS MASYARAKAT (CBSWM) DI KOTA MANADO SEBAGAI PEMENUHAN HAK ATAS LINGKUNGAN HIDUP YANG BAIK DAN SEHAT
}

\author{
Yoan Barbara Runtunuwu ${ }^{1}$ \\ ${ }^{1}$ Program Studi Ilmu Hukum, Universitas Negeri Manado \\ Email: yoanruntunuwu@unima.ac.id \\ Website Jurnal: http://ejurnal.unima.ac.id/index.php/geographia \\ (c) (1) (6) Akses dibawah lisensi CC BY-SA $4.0 \mathrm{http} / / /$ creativecommons.org/licenses/by-sa/4.0/ \\ DOI: $10.53682 /$ gjppg.v2i2.2698 \\ (Diterima: 03-11-2021; Direvisi: 12-12-2021; Disetujui: 14-12-2021)
}

\begin{abstract}
The purpose of this study is an action to study and analyze the problems of waste management in residential areas and residential waste management and community-based waste management. In this study, we use a study based on literature study which is a legal norm, where the x materials obtained through library research are only library materials and legal secondary materials. The essence of this discussion is the implementation of integrated waste management in Manado City based on the provisions regarding waste. It is clearly stated that waste management is not only the responsibility of the government. As a waste producer, the community has to maintain cleanliness and environmental health. In this case, an administrative disposition must be applied to continue any problems found. As mentioned in this field, compliance is low and can provide a deterrent effect for those who are not aware of the importance of waste management.
\end{abstract}

Keywords: CBSWM, Implementation, Waste management

\begin{abstract}
ABSTRAK
Adapun yang menjadi tujuan dari studi ini merupakan tindakan untuk mempelajari dan menganalisis permasalahan pengelolaan sampah di kawasan permukiman dan pengelolaan sampah permukiman dan pengolahan sampah berbasis masyarakat. Dalam penelitian ini kami menggunakan studi berdasarkan studi kepustakaan yang merupakan norma hukum, dimana bahan-bahan sekunder yang diperoleh melalui penelitian kepustakaan yang dicari hanya bahan pustaka dan bahan sekunder hukum. Inti dari pembahasan ini adalah suatu pelaksanaan pengelolaan sampah terpadu di Kota Manado dilatarbelakangi oleh ketentuan mengenai sampah. Dinyatakan secara jelas bahwa pengelolaan sampah tidak hanya tanggung jawab pemerintah. Sebagai penghasil sampah, tugas masyarakat untuk menjaga kebersihan dan kesehatan lingkungan. Dalam hal ini, harus diterapkan disposisi administrative agar dapat melanjutkan setiap masalah yang ditemukan. Seperti disebutkan dibidang ini, kepatuhannya rendah, dan dapat memberikan efek jerah bagi mereka yang tidak menyadari pentingnya pengolahan sampah.
\end{abstract}

Kata Kunci: $C B S W M$, Penerapan, Pengelolaan 


\section{PENDAHULUAN}

Perkembangan saat ini Indonesia sedang mengalami proses pembangunan perkotaan yang pesat. Berbagai kontruksi, seperti pusat perbelanjaan, komersial dan industri berikutnya, seringkali dapat menyerap sumber daya manusia secara umum. Inilah sebabnya mengapa orang terpesona oleh kehidupan perkotaan untuk mempertahankan mata pencahariannya dengan meningkatkan standar hidup. Fakta ini membuat proses urbanisasi sulit diatasi dan berdampak pada peningkatan kepadatan penduduk perkotaan.

Cepatnya peningkatan masyarakat perkotaan, berbagai kegiatan ekonomi dan sosial masyarakat meningkat yang mengarah dalam pada problem kota. Situasi ini diperparah oleh terbatasnya sumber daya pemerintah pusat dan daerah untuk mengatasi masalah ini. Secara umum, suatu kondisi ini, menjadi tantangan bagi pemerintah kota untuk menciptakan lingkungan perkotaan yang dapat mendukung kehidupan seluruh warganya. Masalah lain yang disebabkan oleh peningkatan jumlah penduduk kota adalah peningkatan jumlah sampah. Jumlah berbanding lurus dengan tingkat konsumsi masyarakat terhadap produk atau bahan yang digunakan sehari-hari. Seperti halnya jenis sampah, tergantung pada jenis bahan yang benar-benar dikonsumsi masyarakat. Maka dari itu, pengolahan sampah tidak dapat dipisahkan dari sifat dari penduduk tersebut.

Meningkatnya suatu jumlah penduduk dan gaya hidup secara signifikan mempengaruhi jumlah, jenis, dan keanekaragaman sampah yang dihasilkan. Jika jumlah penduduk masih sedikit dan ruang yang dibutuhkan masih relatif kecil, pembuangan sampah menurut pola pengolahan yang ada cocok digunakan kota Manado. Namun dengan meningkatnya tekanan penduduk, daya beli masyarakat, perkembangan industri, urbanisasi, serta meningkatnya usaha atau kegiatan penunjang pertumbuhan ekonomi suatu daerah juga memberikan kontribusi yang besar terhadap kuantitas dan kualitas sampah yang dihasilkan yang telah mengganggu struktur kota sehingga sistem pengelolaan sampah sudah tidak layak pakai.

Saat ini hampir seluruh pengelolaan sampah berakhir di Tempat Pembuangan Akhir (TPA), sehingga menyebabkan beban TPA menjadi sangat berat. Selain diperlukan lahan yang cukup luas juga diperlukan fasilitas pemeliharaan yang sangat mahal. Semakin banyaknya jumlah sampah yang harus dibuang ke TPA salah satunya disebabkan belum dilakukannya upaya pengurangan volume sampah secara sungguh-sungguh sejak dari sumbernya (Kustiah, 2005).

Proses pengerjaan konvensional dengan sistem open damping yang menumpuk sampah di luar TPA Sumompo bukanlah pilihan yang ramah lingkungan karena gas metana dan lindi dapat mencemari lingkungan sekitar. Selain itu, pengolahan intensif (pusat) di TPA memperpanjang rute transportasi dan mengurangi efisiensi. Adapun suatu, sarana dan prasarana pengolahan sampah yang belum memadai membuat Dinas Pertamanan Kota Manado (DKP) jika operasi pengolahan sampah yang belum optimal. Selain itu, cara pandang masyarakat sebagai penghasil sampah terhadap kesehatan dan kebersihan lingkungan juga perlu dipertanyakan. Dalam hal ini, muncul masalah penyimpangan dari psikologi sosial masyarakat urban bahwa citra dan cita-cita kebersihan dan kesehatan lingkungan hanya berlaku di ranah privat, bukan public. Orang mungkin merasa bersalah membuang sampah di hutan kota, sungai, laut, kebun, dan tanah kosong, karena mereka peduli dengan kebersihan rumah mereka dan tidak peduli dengan lingkungan dan kota. Ironisnya, fasilitas pengolahan sampah di hampir setiap kota di Indonesia masih terbatas. Oleh karena itu, pemerintah mengeluarkan Undang-Undang Pengolahan Sampah No. 18 Republik Indonesia pada tanggal 7 Mei 2008 yang telah disahkan oleh Pemerintah.

Ketentuan mengenai sampah mengatur semua pemangku kepentingan dalam komponen sampah, juga penduduk dan peran serta pelaku bisnis. Kehadiran Undang-Undang tentang Pengelolaan Sampah menurut Ilyas Asaad (Deputi Menteri Negara Lingkungan Hidup Bidang Penataan Lingkungan) dilatarbelakangi beberapa pemikiran: 1) meningkatkan prinsip-prinsip pembangunan berkelanjutan ke seluruh bidang pembangunan, 2) meningkatkan koordinasi pengelolaan lingkungan hidup di tingkat nasional dan daerah, 3) meningkatkan upaya harmonisasi pengembangan hukum lingkungan dalam mendukung prinsip pembangunan berkelanjutan, 4) meningkatkan upaya pengendalian dampak lingkungan akibat kegiatan pembangunan, 5) meningkatkan upaya 
penataan dan penegakan hukum secara konsisten pada pencemar dan perusak lingkungan, 6) meningkatkan kapasitas lembaga dan sumber daya manusia pengelola lingkungan hidup baik di tingkat nasional atau daerah, dan 7) membangun kesadaran masyarakat agar peduli isu lingkungan hidup berperan aktif sebagai kontrol sosial dalam memantau kualitas lingkungan hidup.

Berdasarkan uraian dari penjelasan permasalahan diatas sehingga penulis ingin melaksanakan studi tentang penerapan pengelolaan sampah berbasis masyarakat (CBSWM) di Kota Manado sebagai pemenuhan hak atas lingkungan hidup yang baik dan sehat. Studi dikhususkan di pemukiman masyarakat pada sampah-sampah keluarga.

\section{METODE PENELITIAN}

Penelitian ini menggunakan studi berdasarkan studi kepustakaan normatif hukum dimana studi harus dilakukan untuk menyelidiki bahan pustaka dan bahan hukum (Mamudji \& Rahardjo, 2005). Oleh karena itu suatu bahan dipakai yaitu data sekunder yang didapat dari penelitian dokumen .

Metode penyidikan hukum prespiktif menekankan pada data bantu dengan mengkaji dan menelaah asas-asas hukum baik dalam kasus maupun peraturan peraturan asas hukum atau hukum nasional dan yang relevan dengan persoalan yang dihadapi. Pendekatan yang dipakai merupakan pendekatan santun untuk memunculkan ide-ide dan teori-teori yang dapat digunakan dalam proses penelitian.

Mengingat penelitian hukum normatif, metode yang digunakan adalah normatif, menggunakan prinsip-prinsip hukum dan pendekatan prinsip-prinsip ideal yang sesuai dengan tujuan hukum untuk melindungi hak atas lingkungan hidup yang sehat yaitu pendekatan hukum (Soemitro, 1982).

Langkah selanjutnya adalah analisis data. Bahan atau data yang dikumpulkan bersifat spesifik atau dipilih dan dianalisis dengan menggunakan teori, konsep, dan kaidah hukum yang terkandung dalam suatu kerangka pemikiran untuk memberikan jawaban atas kekhususan permasalahan yang telah diuraikan. Selanjutnya dalam metode investigasi, dilakukan pengumpulan identifikasi atau analisis data, bahan atau data yang dipilih. Jika perlu atau dalam kaitannya dengan tujuan penyelidikan yang dianalisis dengan menggunakan konsep teoritis dan aturan hukum yang terkandung dalam kerangka pemikiran. Langkah yang ini dimaksudkan sebagai analisis bahan hukum. Pemikiran tersebut untuk memberikan jawaban atas masalah yang identifikasi (Hartono, 2010).

\section{HASIL PENELITIAN DAN PEMBAHASAN}

Penerapan pengelolaan sampah terpadu di Kota Manado diatur dalam Undang-Undang Nomor 18 Tahun 2008 tentang pengolahan sampah. Ditegaskan bahwa pengolahan sampah bukan hanya menjadi tanggung jawab pemerintah. Sebagai penghasil sampah, masyarakat juga bertanggung jawab menjaga kebersihan dan kesehatan lingkungan. Dari undang-undang, pemerintah memberikan ruang hidup bagi pemerintah pusat, kota/kabupaten untuk menata dan mengelola sampah di wilayahnya. Ketentuan turunan UU Pengolahan Sampah 2010 dan Permendagri Nomor 33 tentang Pengolahan Sampah. Permendagri ini mengatur tentang pengolahan sampah $3 \mathrm{R}$ yang mewajibkan pengelola sampah untuk mengklasifikasikan dan memisahkan sampah organik dan nonorganik dan membuangnya ke tempat sampah yang disediakan sendiri.

Limbah domestik diolah di DKP Kota Manado, yang memiliki fasilitas seperti kecamatan khusus, fasilitas umum, dan fasilitas sosial di kawasan komersial dan industri. Kompensasi finansial untuk praktik pengolahan sampah berasal dari retribusi yang dipungut berdasarkan Peraturan Daerah No. 7 tahun 2006 untuk biaya pengolahan sampah dan kebersihan di Kota Manado. Di sisi lain, sampah rumah tangga diolah oleh pihak ketiga LPM (Lembaga Pemberdayan Masyarakat) dalam hal ini, sampah diangkut ke tempat pembuangan sampah terpadu (TPST) di desa untuk pembuangan sampah rumah tangga. Sisa sampah yang belum diolah akan dikirim gratis dari DKP Kota Manado ke TPA Sumompo karena ada subsisi silang di luar pemukiman. LPM di bidang pengolahan sampah diberikan penghargaan berupa sumbangan dari setiap rumah tangga sesuai musyawarah mufakat.

Meskipun peraturan ini diatur oleh pemerintah Kota Manado, namun tidak serta merta memfasilitasi pembuangan limbah luar ruangan. Situasi pengolahan sampah di manado, khususnya di kawasan pemukiman, tampaknya masih kacau yang di ukur dengan 
sistem dan metode pengolahan sampah yang efektif, aman, sehat, ramah lingkungan dan ekonomis.

Pada Peraturan Daerah Kota Manado Nomor 1 Tahun 2021 tentang Pengelolaan Sampah, aturan ini memungkinkan masyarakat untuk berperan aktif dalam pengolahan sampah dengan cara; 1) meningkatkan kapasitas, kemandirian, perizinan, dan kemitraan pengolahan sampah, 2) membina masyarakat yang menjadi pionir dalam pengolahan sampah, 3) memperkuat tanggap darurat atau emergency action dalam pengolahan sampah termasuk kebakaran berbahaya di TPS 3R, TPST, TPA, 4) melaporkan informasi terkait pengolahan sampah, pengajuan pengaduan, saran dan atau kritik, dan 5) memberikan pendidikan dan pelatihan kelompok masyarakat, kampanye dan dukungan kepada anggota masyarakat di bidang pengolahan sampah untuk mengubah perilaku serta masyarakat.

Adapun dalam hal ini termasuk masyarakat adalah penghasil sampah. Sesuai dengan peraturan daerah, masyarakat juga harus menyediakan tempat sampah dan terlibat dalam pengolahan sampah. Wadah untuk setiap rumah dimaksudkan sebagai penampung. Limbah rumah tangga tersebut dapat diolah dengan baik agar tidak mencemari lingkungan, dan udara menjadi sehat.

Akibat dari penelusuran sampah yang berserakan, kurangnya kesadaran masyarakat terhadap sampah menyebabkan pencemaran lingkungan terutama di pemukiman penduduk, jika sampah tidak dikelola dengan baik akan memperparah dengan pencemaran lingkungan. Tidak baik untuk kesehatan.

Dalam hal ini untuk bisa menindak lanjuti segala hal yang terdeteksi, sanksi administratif yang nantinya bisa menjatuhkan sanksi bagi masyarakat yang tidak mematuhi peraturan dan tidak sadar akan pentingnya pengolahan sampah harus diterapkan. Dengan tambahan sanksi Perda Nomor 1 Tahun 2021 Pasal 51, dimungkinkan terwujudnya hakvatas lingkungan hidup yang sehat dan baik di kawasan permukiman di Kota Manado.

\section{KESIMPULAN}

Penerapan pengelolaan sampah terpadu di Kota Manado didasarkan pada Undangundang Nomor 18 Tahun 2008 tentang pengolahan Sampah. Jelas disebutkan bahwa pengolahan sampah bukan tanggung jawab pemerintah. Masyarakat yang menghasilkan sampah juga bertanggung jawab untuk menjaga lingkungan yang bersih dan sehat. Melalui peraturan perundang-undangan, pemerintah memberikan ruang hidup bagi pemerintah pusat, kota/kabupaten untuk menata dan mengolah sampah diwilayahnya. Dalam hal ini, harus diterapkan disposisi administratif untuk memastikan bahwa setiap masalah yang ditemukan dapat dilanjutkan. Hal ini dapat memberikan efek jera di kemudian hari bagi masyarakat yang memiliki kepatuhan rendah dan tidak menyadari pentingnya pengolahan sampah, seperti yang tertuang dalam peraturan daerah Pasal 51 Nomor 1 Tahun 2021.

\section{SARAN}

Perlu adanya sanksi yang tegas bagi masyrakat tidak patuh dalam menjaga kebersihan dan kesehatan lingkungan. Sinergi antara pemerintah kota dan masyarakat dalam pengelolaan sampah dapat dilakukan dengan pemberian intensif biaya atau peralatan pengelolaan sampah. Dengan begitu akan semakin menumbuhkan kesadaran akan pentingnya lingkungan yang baik dan sehat.

\section{DAFTAR PUSTAKA}

Hartono, C. F. G. S. 2010. Penelitian Hukum di Indonesia. Bandung: Alumni.

\section{Kustiah, T. 2005. Kajian Kebijakan Pengelolaan Sanitasi Berbasis Masyarakat. Bandung: Pusat Penelitian Dan Pengembangan Departemen Pekerjaan Umum.}

Mamudji, S., dan Rahardjo, H. 2005. Metode Penelitian dan Penulisan Hukum. Jakarta: Badan Penerbit Fakultas Hukum Universitas Indonesia.

Soemitro, R. H. 1982. Metode Penelitian Hukum. Ghalia Indonesia, Semarang. 